\title{
Effects of Public External Debt and Private Investment on Agricultural Growth in Nigeria: 1980-2016
}

\author{
Ukpe $\mathrm{UH}^{1 *}$, Umeh $\mathrm{JC}^{2}$, Ater $\mathrm{PI}^{2}$ and Asogwa $\mathrm{BC}^{2}$ \\ ${ }^{1}$ Department of Agricultural Economics and Extension, Federal University Wukari, Nigeria \\ ${ }^{2}$ Department of Agricultural Economics, Federal University of Agriculture Makurdi, Nigeria
}

Submission: August 12, 2016; Published: August 23, 2017

"Corresponding author: Ukpe UK, Department of Agricultural Economics and Extension, Federal University Wukari, Nigeria, Tel: 08020511613; Email: henrietta2elle@gmail.com

\begin{abstract}
The recent debate of research interest is the conflicting view with respect to public debt and empowerment of private sector as drive for sustainability of the economy in general and agric sector in particular. This study examined the effects of private investment and public external debt on agricultural growth in Nigeria from 1980 to 2016. Data were collected from secondary sources and were analysed using fully modified ordinary least square. The result showed that the coefficient of determination (R2) was 0.65 indicating that $65 \%$ of the variation of agricultural output was explained by public external debt, foreign direct investment, domestic private investment and labour. The result also showed that the coefficients of public external debt $(-0.315)$ and domestic private investment $(-0.488)$ were significant and negative indicating that unit increase in public external debt and domestic private investment decrease agricultural growth by 0.315 metric tons and 0.488 metric tons respectively. In contrast, the coefficient of labour (1.487) was positive and significant indicating that unit increase in labour will increase agricultural growth by 1.487 metric tons. It was therefore recommended that specialized development agencies should be set up with the aim of implementing and evaluating government policies on foreign external debt and domestic private investment.
\end{abstract}

Keywords: Agricultural growth; Public external debt; Domestic private investment; Foreign direct investment

\section{Introduction}

It is generally expected that developing countries, facing a scarcity of capital will acquire external loan building up her external debt to supplement domestic saving [1]. Besides, external borrowing is preferable to domestic debt because the interest rates charged by international financial institutions like International Monetary Fund (IMF) is about half the one charged in the domestic market [2]. The issue of Nigeria's public debt became important in recent times especially prior to the period of debt forgiveness because of its magnitude and the amount which was required to service such debts, as well as, its attendant possible effects on different operating sectors of the economy especially the banking sector and the growth of the economy at large [3]. External debt burden in Nigeria can be traced to so many factors in the past which caused the growth of the economy to decline alongside its development. Heavy external debt burden nevertheless, may have been associated with disincentives to invest, which could have contributed to the relatively poor growth performance of Nigeria in the past.

The relationship among saving, investment and growth has historically been very close; hence, the unsatisfactory growth performance of several developing countries has been attributed to poor saving and investment $[4,5]$. Foreign private investment could play an important role in the economic development of a country especially a developing one like Nigeria. Foreign direct investment surpasses all other forms of lending as a source of foreign capital to developing countries because it disseminates advanced technology and managerial practices through the host country and thereby exhibit greater positive externalities compared to foreign portfolio investment which may not involve positive transfer but just a change in ownership. In addition, available data suggests that foreign direct investment flows tend to be more stable compared to foreign portfolio investment $[6,7]$. 
Agricultural sector has been a key driver of recent economic growth in Nigeria, accounting for 70 percent of GDP of the non-oil sector [8] and providing subsistence for two-third of Nigerians who are low income earners [8,9] from 1980 to 2011 [10]. It also accounted for 19.17 of the total GDP in the first quarter of 2016 [11]. It is the single most important sector in Nigeria and some other african countries, providing livelihood for at least 53 percent of the economically active labour force [8].

External loan has the inherent capacity to promptly put a country on developmental pedestal, but, as it has been, its misuse involves huge social and human costs. External debt rather than decrease has been on the increase, particularly with the insurmountable regime of debt servicing and the insatiable desire of political leaders to obtain loans for the execution of projects without adequate planning [12]. Foreign direct investment (FDI) inflows to Nigeria have remained low compared to other developing countries though the growth has remained positive. It has been hypothesized that the response of private investors depends on the stage of the economy's business cycle, the availability of financing and the level of public investment. Gyong [13] and Iyoha [14] posit that the deleterious effect of escalating external debt has been aggravated by domestic macroeconomic policy deficiencies that have resulted in declining per capita, uneven growth of real GDP and rising inflation. The noticeable fall in the ratio of private sector investment to GDP in spite of the emphasis on private sector following the introduction of public sector reforms is even more perturbing [15]. The null hypothesis for this study is stated thus: H01: Private investment and public external debt have no significant effect on agricultural growth.

\section{Literature Review}

\section{Public External Debt in Nigeria}

Many developing countries resort to external borrowing to bridge the domestic resource gap in order to accelerate economic development [16]. Udeh et al. [17] in their view believed that the quest for economic growth and development compelled Nigeria to acquire external debt. External loan has the inherent capacity to promptly put a country on developmental pedestal, but, as it has been, its misuse involves huge social and human costs. It could also lead to decline in the country's external assets and decline in the productive capacity of the national economy with all its attendant effects on macroeconomic environment [18]. The first major external loan of US $\$ 28$ illion by Nigeria was acquired from World Bank in 1958 to finance railway construction. Ever since then, there has been accumulation of loans aimed at various development projects without obvious results as expected.

\section{Foreign Direct Investment (FDI) in Nigeria}

Macaulay [19] asserted that Nigeria's foreign investment can be traced back to the colonial era, when the colonial masters had the intention of exploiting our resources for the development of their economy. There was little investment by these colonial masters. With the research and discovery of oil foreign investment in Nigeria, but since then, Nigeria's foreign investment has not been stable. The Nigerian governments have recognized the importance of FDI in enhancing economic growth and development and various strategies involving incentive policies and regulatory measure have been put in place to promote the inflow of FDI to the country. Shiro [20] noted that since the enthronement of democracy in 1999, the government of Nigeria has taken a number of measures necessary to woo foreign investors into Nigeria. These measures, he noted, include the repeal of laws that are inimical to foreign investment growth, promulgation of investment laws, various oversea trips for image laundry by the President among others.

\section{Domestic Private Investment in Nigeria}

In Nigeria, the economy witnessed tremendous growth in the 1970s and early 1980s as a result of the oil boom. Following the oil boom, there was investment boom especially in the public sector. However, with the collapse of the oil market in the 1980s, investment fell, thereby resulting in a fall in economic growth [21]. In recent years, successive government in Nigeria in attempt to promote investment and growth has formulated several policies prominent among which is the National Economic Empowerment and Development Strategies (NEEDS). In the first years of the reforms, the share of banking system's credit to the private sector improved and superseded the flows to government for the first time in five years. The bulk of the credit that was channeled to private sector was mainly directed towards short-term investment [08,22].

\section{Agricultural growth in Nigeria}

Nigeria is an agrarian country with about $70 \%$ of her over 140 million people engaging in agricultural production and provides subsistence for two-thirds of Nigerians who are low income earners [9]. Nigerian agriculture consists of large numbers of smallholder farmers, scattered across the Country. This self-perpetuating web is said to inhibit the participation of the traditional farmers in economic development [23]. In order to revamp the agricultural sector, the federal government had embarked on and implemented several agricultural policies and programmes some of which are defunct or abandoned, and some restructured while others are still in place.

\section{Methodology}

\section{Study area}

Nigeria is situated in the West African region and lies between longitudes $3^{\circ}$ and $14^{\circ}$ East and latitudes $4^{\circ}$ and $14^{\circ}$ North. Nigeria's ecology varies from tropical forest in the south to dry savanna in the far north, yielding a diverse mix of plant and animal life. Nigeria's wide range of climate variations allows it to produce a variety of food and cash crops [24]. Nigeria's external debt profile has been on the increase except for the period of debt forgiveness. 


\section{Data collection}

To examine the effects of public external debt and private investment on agricultural growth, the secondary data of public external debt, domestic private investment, foreign private investment, labour force and agricultural output consisting of annual time series covering a period of 37 years (1980-2016) were obtained from World Bank development indicators data base and United Nation Conference on Trade and Development (UNCTAD) stat.

\section{Data analysis}

Fully modified Ordinary Least Square (FMOLS) was used to analyse the effects of public external debt and private investment on agricultural growth. Various modern econometric techniques have been introduced to investigate the existence of a longrun relationship among variables. The FMOLS method was originally introduced and developed by Philips and Hansen [25] for estimating a single co-integrating relationship that has a combination of I(1) [26]. The FMOLS method has an advantage over the Engle-Granger (EG) techniques in introducing appropriate correction to overcome the inference problem in EG method and hence, the t-test for long-run estimates is valid [27].

\section{Model specification}

Fully Modified ordinary Least Square (FMOLS)

The model specification of FMOLS for this study is specified as:

$\operatorname{In} A G_{t}=\alpha_{1} \operatorname{In} P E D_{t}+\alpha_{2} \operatorname{InFDI} I_{t}+\alpha_{3} \operatorname{InDPI} I_{t}+\alpha_{4} \operatorname{In} L_{t}+u_{t}(1)$

Where,

AG: Agricultural Growth (agricultural production in million US Dollar)

PED: Public External Debt (million US Dollar)

GDPI: Gross Domestic Private Investment (million US Dollar)

FDI: Foreign Direct Investment (million US Dollar)

L: Labour Force (million)

U: Error Term

Ln: Natural Logarithm

EC: Estimated Coefficients

Table 1: Unit root test (ADF TEST).

\begin{tabular}{|c|c|c|c|c|c|}
\hline & \multicolumn{3}{|c|}{ ADF Results } & At level & \multicolumn{2}{c|}{ At first difference } & Pecision \\
\hline & \multicolumn{2}{|c|}{ Probability } & I(1) \\
\hline Agricultural Growth & 0.65339 & 0.8526 & -0.9335604 & $0.0000^{* * *}$ & I(1) \\
\hline $\begin{array}{c}\text { Domestic private } \\
\text { investment }\end{array}$ & -1.35114 & 0.5949 & -2.408336 & $0.0011^{* *}$ & $\mathrm{I}(1)$ \\
\hline $\begin{array}{c}\text { Foreign direct } \\
\text { investment }\end{array}$ & -1.88790 & 0.6400 & -5.121985 & & $\mathrm{I}(1)$ \\
\hline Labour force & 4.62510 & 1.0000 & & & $\mathrm{I}(0)$ \\
\hline Public external debt & -2.03007 & 0.2732 & -4.055632 & $0.0034^{* *}$ & $\mathrm{I}(1)$ \\
\hline
\end{tabular}

${ }^{* * *},{ }^{* *}$ and ${ }^{*}$ indicate stationary at $1 \%, 5 \%$ and $10 \%$ level of significance respectively

Table 2: Unrestricted Cointegration Rank Test Result.

\begin{tabular}{|c|c|c|c|c|}
\hline Hypothesized No of CE(s) & Eingen Value & Trace Statistics & $\mathbf{0 . 0 5}$ Critical Value & Prob** \\
\hline None* & 0.41261 & 21.42205 & 12.32090 & 0.0012 \\
\hline At most 1 & 0.11049 & 3.83374 & 4.129901 & 0.0585 \\
\hline
\end{tabular}

${ }^{*}$ Denotes rejection of the hypothesis at 0.05

**Mackinnon-Haug-Michells (1999) p-values

Source: EViews computation

Table 3: Effects of Public External Debt and Private Investment on Agricultural Growth.

\begin{tabular}{|c|c|c|}
\hline Variables & Coefficient & t-statistic \\
\hline Domestic private investment & $-0.49^{* *}$ & -2.18 \\
\hline Foreign direct investment & 0.14 & 0.85 \\
\hline Labour force & $1.49^{* *}$ & 2.34 \\
\hline Public external debt & $-0.32^{* *}$ & -2.43 \\
\hline
\end{tabular}




\section{Durbin-Watson stat}

** significant at $5 \%$

Source: EViews computation, 2017

Results

(Table 1-3)

\section{Discussion}

\section{Stationarity test (Unit Root Test)}

The result of the stationarity test is presented on Table 1. The result shows that labour force was stationary at level while agricultural growth, domestic private investment, foreign direct investment and public external debt were stationary at first difference.

\section{Johansen cointegration test}

Lack of cointegration suggests that such variables have no long run relationship. The result of the unrestricted Johansen cointegration test at $5 \%$ level of significance is presented on Table 2. The result shows that the trace statistic (21.42205) was greater than the critical value (12.32090) implying one cointegrating equation which indicates the long run relationship among variables.

\section{Effects of public external debt and private investment on agricultural growth}

The effect of public external debt and private investment on agricultural growth is presented on Table 3 . The result showed that the coefficient of determination (R2) was 0.65 indicting that 65 percent of the variation in agricultural growth was explained by domestic private investment, public external debt, foreign direct investment and labour force. The result further showed that domestic private investment, labour force and public external debts were the variables that significantly affected agricultural growth. Specifically, the coefficient of labour force (1.49) was positive and significant at 5\% indicating that increasing labour force by one increased agricultural growth by 1.49 metric tons which is attributed to the fact that agricultural sector employs majority of the active population. This result agrees with Umoru [28] who found that labour influence economic growth of Nigeria positively. In contrast, the coefficients of domestic private investment (-0.49) and public external debt (-0.32) were negative and significant at $5 \%$ indicating that increases in domestic private investment and public external debt respectively by US\$ 1 decreased agricultural growth by 0.47 metric tons and 0.32 metric tons respectively. This is due to the fact that most domestic private investors did not invest into agricultural sector and the external debt borrowed was not invested directly to the agricultural sector. Therefore, the null hypothesis which stipulated that public external debt and private investment have no significant effect on agricultural growth in Nigeria was hereby rejected. These results disagree with Ikudayisi et al. [29] and Kalu \& Mgbemena [30] who found that public external debt increased the economic growth of Nigeria and domestic private investment increased economic growth of Nigeria respectively. However, the coefficient of foreign direct investment had no significant effect on agricultural growth.

\section{Conclusion and Recommendation}

This study examined the effects of public external debt and private investment on agricultural growth in Nigeria. The result also showed that public external debt and domestic private investment negatively affected the agricultural growth in Nigeria during the period under review.

Based on the aforementioned, it was recommended that specialized development agencies should be set up with the aim of implementing and evaluating government policies on foreign external debt and domestic private investment.

\section{References}

1. Aluko F, Arowolo D (2010) Foreign aid, the Third World's debt crisis and the implication for economic development: The Nigerian experience. African Journal of Political Science and International Relations 4(4): 120-127.

2. Ayadi FS, Ayadi FO (2008) The Impact of External Debt on Economic Growth: A comparative study of Nigeria and South Africa. Journal of Sustainable Development in Africa 10(3): 234-264.

3. Saheed ZS, Sani IE, Idakwoji BO (2015) Impact of Public External Debt on Exchange Rate in Nigeria. European Journal of Business and Management 7(21): 51-57.

4. Tochukwu N (2012) Determinant of Savings in Nigeria. Journal of Monetary \& Economic Integration 11(2).

5. Osmond CA (2015) Determinants of Private Investment in Nigeria: An Econometric Analysis. International Journal of Economics, Commerce and Management III(4): 1-14.

6. Lipsey RI (1999) The Role of Foreign Direct Investment in International Capital Flows. NBER working paper pp. 7094.

7. Oni TO, Imolehin OA, Adelowo WB, Adejumo AV (2014) Foreign Private Investment and Economic Growth in Nigeria (1980 - 2010). International Journal of Development and Economic Sustainability 2(1): 39-48.

8. Akpaeti AJ, Bassey NE, Okoro US, Nkeme KK (2014) Trends and Drivers of Agricultural Investments and Growth in Nigeria: The Pre and Financial Sector Reforms Experience. Asian Journal of Economic Modelling 2(3): 115-127.

9. Usman NE (2006) Agriculture: Vital to Nigerian Economic Development. Economic Stakeholders on "Growing the Nigeria Economy" 2006.

10. Okezie AI, Nwosu C, Njoku AC (2013) An assessment of Nigeria expenditure on the agricultural sector: Its relationship with agricultural output (1980 - 2011). Journal of Economics and International Finance 5(5): 177-186.

11. NBS (2017) Labour Productivity Report Q3 2016. National Buraeu of Statistics pp. 1-6.

12. Essien EA, Onwuoduokit EA (2009) Nigeria's Economic Growth and 
Foreign Debt. CBN Economic Review 36(1).

13. Gyong YE (2014) Impact of external debt on economic growth in Nigeria: 1980-2011. Yobe Journal of Economics 1(1): 96-97.

14. Iyoha MA (2000) The Impact of External Debt Reduction on Economic Growth in Nigeria. The Nigeria Economic Society. pp. 235-262.

15. Imoisi AI, Abuo M, Sogules IW (2015) Domestic Investment and Economic Growth in Nigeria from 1970-2013: An Economic Analysis. Canadian Social Science Journal 11(6): 70-79.

16. Oke MO, Sulaiman LA (2012) External Debt, Economic Growth and Investment in Nigeria. European Journal of Business and Management 4(11): 67-76.

17. Udeh SN, Ugwu JI, Onwuka IO (2016) External Debt and Economic Growth: The Nigeria Experience. European Journal of Accounting Auditing and Finance Research 4(2): 33-48.

18. Adebiyi WK, Olowookere JK (2013) Managing Nigerian Debt: The Practical Solutions. Research Journal of Finance and Accounting 4(19): 116-225.

19. Macaulay ED (2012) Foreign Direct Investment and the Performance of the Nigerian Economy. Proceedings of the $1^{\text {st }}$ International Technology, Education and Environment Conference, pp. 629-633.

20. Shiro AA (2009) The Impact of FDI on the Nigerian Economy. $2^{\text {nd }}$ National Conference, Finance, University of Lagos, Nigeria.

21. Agu OC (2015) Determinants of private investment in Nigeria: An econometric analysis. International Journal of Economics, Commerce and Management III(4): 1-14.

22. Emenuga C (1996) The outcome of financial sector reforms in West Africa. pp. 14-17.
23. Nwosu AC (2004) Private sector initiatives in agricultural development in Nigeria. In: Nnanna OJ, Okafor CM, et al. (Eds.), Central bank of Nigeria. Proceedings of the Thirteenth Annual Conference of the Regional Research Unit, Theme: Enhancing Private Sector-Led Growth in Nigeria Held at motel Benin Plaza, Nigeria.

24. Abdullahi A (2003) Employment creation and opportunities in the agro-allied sub-sector: The case of cassava production. CBN Bullion Publication 27(4): 10

25. Phillips PCB, Hansen B (1990) Statistical Inference in Instrumental Variables Regression with I(1) Processes. The Review of Economic Studies 57(1): 99-125.

26. Al-Abdulrazag B, Amani JS (2014) Immigration and Economic Growth in Jordan: FMOLS Approach. International Journal of Humanities Social Sciences and Education 1(9): 85-92.

27. Himansu AA, Lester CH (2007) Electricity Demand for Sri Lanka: A Time Series Analysis. Surrey Energy Economics Discussion pp. 118.

28. Umoru D (2013) Employment and Economic Growth in Nigeria: A Bounds Specification. Journal of Economics and Sustainable Development 4(5): 49-61.

29. Ikudayisi A, Akin-Olagunju O, Babatunde A, Irhivben B, Okoruwa V (2015) Nigerian Debt Portfolio and Its Implication on Economic Growth. Journal of Economics and Sustainable Development 6(18): 87-99.

30. Kalu CU, Mgbemena OO (2015) Domestic Private Investment and Economic Growth in Nigeria: Issues and Further Consideration. International Journal of Academic Research in Business and Social Sciences 5(2): 302-314.

This work is licensed under Creative

Commons Attribution 4.0 License

DOI: 10.19080/ARTOAJ.2017.10.555783

\section{Your next submission with Juniper Publishers} will reach you the below assets

- Quality Editorial service

- Swift Peer Review

- Reprints availability

- E-prints Service

- Manuscript Podcast for convenient understanding

- Global attainment for your research

- Manuscript accessibility in different formats

( Pdf, E-pub, Full Text, Audio)

- Unceasing customer service

Track the below URL for one-step submission https://juniperpublishers.com/online-submission.php 